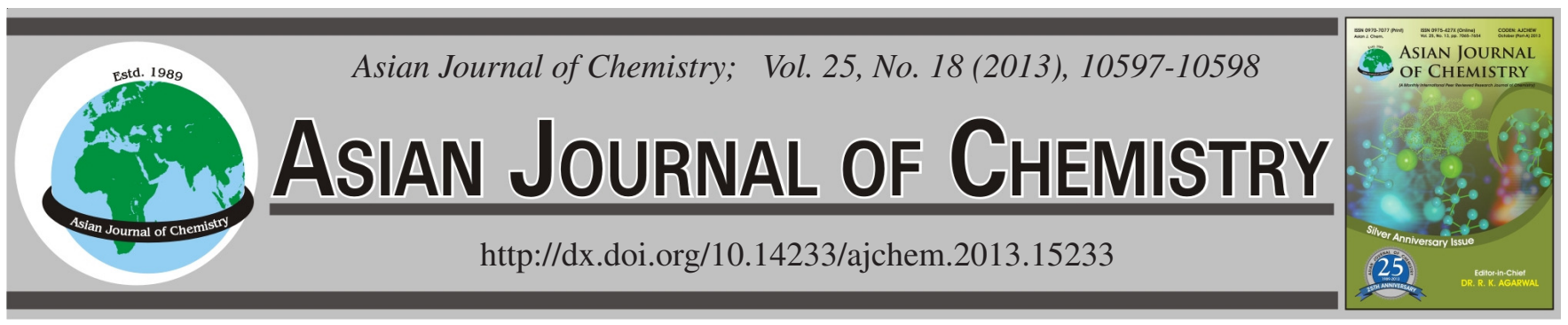

NOTE

\title{
Catalytic Oxidation of N-Phosphonomethyliminodiacetic Acid to Synthesize N-Phosphonomethylylycine
}

\author{
Yufang $\mathrm{XU}^{1}$, Shujuan Dai ${ }^{1}$ and Tianyun $\mathrm{CHEN}^{2, *}$
}

${ }^{1}$ Department of Pharmacy, Anhui Medical College, Hefei 230601, P.R. China

${ }^{2}$ School of Chemical Engineering, Hefei University of Technology, Hefei, 230009, P.R. China

*Corresponding author: Tel/Fax: +86 15955116089; E-mail: 15955116089@163.com

(Received: 29 January 2013;

Accepted: 28 November 2013)

AJC-14455

\begin{abstract}
A process of preparing the herbicide N-phosphonomethylylycine by oxidizing N-phosphonomethyliminodiacetic acid was investigated. The content of N-phosphonomethylylycine was above $75.04 \%$. The solid yield was $73.34 \%$ and the total yield was $87.63 \%$ when the reaction was carried out with the mol ratio of the manganese salt catalyst and $\mathrm{N}$-phosphonomethyliminodiacetic acid as $0.04: 1$ at $80{ }^{\circ} \mathrm{C}$ under $0.4 \mathrm{MPa}$ for $90 \mathrm{~min}$.
\end{abstract}

Key Words: N-Phosphonomethyliminodiacetic acid, N-Phosphonomethylylycine, Transition metal.

Herbicides are widely used by farmers, commercial agricultural companies and other industries to increase crops as corn, soybeans, rice, etc. and to eliminate weed growth along highways, railroad rights-of-way and other areas. While $\mathrm{N}$-phosphonomethylglycine (glyphosate/PMG) is one of the best and most frequently used herbicides ${ }^{1-3}$. N-Phosphonomethylylycine has high affect, low toxicity, good bioactivity and can destroy the ruderal in bud ${ }^{4}$. Industrial uses include control of weeds along roadsides, waterways, transmission lines, in storage areas and in other nonagricultural areas.

In previous years, many methods ${ }^{5-8}$ are explored. As described in the US Pat. No. $3160632^{9}$, a reaction of Nphosphonomethylylycine with mercuric chloride in a water solvent at reflux temperature and subsequently separating the reaction products was shown. US Pat. No. $3950402^{10}$ described a process for the production of N-phosphonomethylglycine by heating an admixture of $\mathrm{N}$-phosphonomethylimiodiacetic acid, water and a metallic catalyst selected from the noble metals to an elevated temperature. In view of the problems of environmental pollution associated with the use of mercury compounds, this method is obviously undesirable for large scale manufacturing use. Riley et al. ${ }^{11}$ reported a process using hydrogen peroxide oxidation $\mathrm{N}$-phosphonomethylimiodiacetic acid to prepare glyphosate by vanadium (IV,V) salts as homogeneous catalysts. The yield of glyphosate can reach $74 \%$. The preparation of a high content of vanadium(IV,V) salts catalyst is difficult to industrialize.
A method which accepts the supported transition metal to oxidize the N-phosphonomethyliminodiacetic acid to produce $\mathrm{N}$-phosphonomethylglycine is investigated in this paper and it is really a valuable method to synthesize $\mathrm{N}$-phosphonomethylglycine.

UV-2550 ultraviolet and visible spectrophotometer was used to compute concentration. All chemicals used in the experiments were analytical grade and used without any further purification.

Quantitative N-phosphonomethyl-iminodiacetic acid (PMIDA), water and catalyst were placed in an autoclave, then heated to a certain temperature for some time. After oxygen was passed into the system to replace air, the autoclave was sealed and kept at certain pressure with oxygen. When the reaction was completed, the autoclave was opened. The catalyst was removed by filtration and the filter liquor was washed with water $(3 \times 10 \mathrm{~mL})$. The production dried and analyzed by UV.

N-Phosphonomethylglycine (PMG) is a non-selective post emergence herbicide, exhibiting strong activity involving disturbance of enzymatic process in plant. We produced $\mathrm{N}$-phosphonomethylglycine from N-phosphonomethyliminodiacetic acid (PMIDA) by transition metal salt oxidants. The possible mechanism is shown in Fig. 1. Several transition metals salts were used in this reaction and the results are shown in Table-1.

As can be seen from Table-1, several metal ions are capable of catalyzing the molecular oxygen oxidation of $\mathrm{N}$ - 


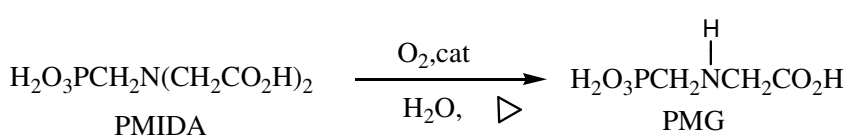

Fig. 1. Possible mechanism

\begin{tabular}{ccccc}
\multicolumn{5}{c}{ TABLE-1 } \\
\multicolumn{5}{c}{ EFFECT OF TRANSITION METAL } \\
SALTS IN THE REACTION
\end{tabular}

${ }^{a}$ All reactions were carried out with $\mathrm{N}$-phosphonomethylimiodiacetic acid $(10 \mathrm{~g})$, water $(400 \mathrm{~mL})$ and catalyst $(0.04 \mathrm{mmol})$ under $80^{\circ} \mathrm{C}$ for $90 \mathrm{~min}$ in autoclave at $0.4 \mathrm{MPa}$.

phosphonomethyliminodiacetic acid to N-phosphonomethylglycine. Of these metal ions, manganese salt was the most active catalyst. Manganese salt is a good catalysis in this system for its good solubility, while carbon catalyst showed a bad efficiency.

In order to ascertain the optimum conditions, several reactions were carried out with manganese salt as catalyst. The effect of temperature on synthesis $\mathrm{N}$-phosphonomethylylycine in the water was carefully investigated. The results are shown in Table-2.

\begin{tabular}{ccccc}
\multicolumn{5}{c}{ TABLE-2 } \\
\hline Entry & $\begin{array}{c}\text { Temp. } \\
\left({ }^{\circ} \mathrm{C}\right)\end{array}$ & $\begin{array}{c}\text { Solids } \\
(\%)\end{array}$ & $\begin{array}{c}\text { Solid glyphosate } \\
\text { yield }(\%)\end{array}$ & $\begin{array}{c}\text { Solid glyphosate } \\
\text { total yield }(\%)\end{array}$ \\
\hline 1 & 70 & 60.94 & 41.92 & 64.96 \\
2 & 80 & 64.85 & 59.95 & 70.91 \\
3 & 90 & 59.01 & 54.29 & 66.08 \\
4 & 100 & 54.83 & 49.95 & 62.95 \\
\hline
\end{tabular}

${ }^{a}$ All reactions were carried out with $\mathrm{N}$-phosphonomethylimiodiacetic acid $(10 \mathrm{~g})$, water $(400 \mathrm{~mL})$ and manganese salt catalyst $(0.04 \mathrm{mmol})$ under certain temperature for $90 \mathrm{~min}$ in autoclave at $0.4 \mathrm{MPa}$.

As shown in Table-2, the per cent of solids, solid glyphosate yield and solid glyphosate total yield increased with the temperature and reached the maximum at $80^{\circ} \mathrm{C}$. Further increasing the temperature to 90 and $100{ }^{\circ} \mathrm{C}$, the per cent of solids, solid glyphosate yield and solid glyphosate total yield dropped for the by-product producing in the progress. For the reaction is gas-liquid reaction, pressure plays an important effect on the reaction. The effect of pressure was investigated. The results were shown in Table-3.

TABLE-3

EFFECT OF REACTION PRESSURE

\begin{tabular}{ccccc}
\hline Entry & $\begin{array}{c}\text { Pressure } \\
(\mathrm{MPa})\end{array}$ & $\begin{array}{c}\text { Solids } \\
(\%)\end{array}$ & $\begin{array}{c}\text { Solid glyphosate } \\
\text { yield }(\%)\end{array}$ & $\begin{array}{c}\text { Solid glyphosate } \\
\text { total yield }(\%)\end{array}$ \\
\hline 1 & 0.2 & 62.23 & 57.41 & 68.17 \\
2 & 0.3 & 64.75 & 59.47 & 71.58 \\
3 & 0.4 & 67.16 & 61.98 & 74.07 \\
4 & 0.5 & 60.44 & 53.16 & 66.47 \\
\hline
\end{tabular}

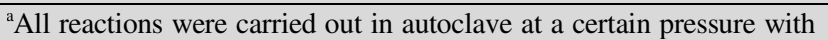
$\mathrm{N}$-phosphonomethylimiodiacetic acid $(10 \mathrm{~g})$, water $(400 \mathrm{~mL})$ and manganese salt catalyst $(0.04 \mathrm{mmol})$ under $80^{\circ} \mathrm{C}$ for $90 \mathrm{~min}$.
As shown in Table-3, with the increase of reaction pressure, the per cent of solids, solid glyphosate yield and solid glyphosate total yield increased. The highest yield was obtained at 0.4 MPa. With the further increase of pressure, the yield of glyphosate was greatly decreased. It may be due to the rate of side reaction and the oxidation rate were sensitive to oxygen. So the optimal reaction pressure was found to be around $0.4 \mathrm{MPa}$.

The effect of the amount of manganese salt for the oxidation reaction was investigated at the optimal temperature (Table-4). Increasing the amount of catalyst, the per cent of solids, solid glyphosate yield and solid glyphosate total yield were also increased. When the amount of catalyst was up to $0.05 \mathrm{mmol}$, the yield was decreased. So the optimal amount of catalyst was found to be around $0.04 \mathrm{mmol}$.

\begin{tabular}{ccccc}
\multicolumn{5}{c}{ TABLE-4 $^{\text {EFFECT OF AMOUNT OF MANGANESE SALT CATALYST }}$} \\
\hline \multirow{2}{*}{ Entry } & $\begin{array}{c}\text { Amount of } \\
\text { catalyst } \\
\text { mmol }\end{array}$ & Solids (\%) & $\begin{array}{c}\text { Solid } \\
\text { glyphosate } \\
\text { yield }(\%)\end{array}$ & $\begin{array}{c}\text { Solid } \\
\text { glyphosate } \\
\text { total yield (\%) }\end{array}$ \\
\hline 1 & 0.02 & 62.67 & 54.12 & 67.16 \\
2 & 0.03 & 67.84 & 66.19 & 78.25 \\
3 & 0.04 & 71.19 & 69.37 & 82.57 \\
4 & 0.05 & 67.92 & 52.43 & 65.81 \\
\hline
\end{tabular}

${ }^{a}$ All reactions were carried out with N-phosphonomethylimiodiacetic acid $(10 \mathrm{~g})$, water $(400 \mathrm{~mL})$ and manganese salt catalyst under $80{ }^{\circ} \mathrm{C}$ for $90 \mathrm{~min}$ in autoclave at $0.4 \mathrm{MPa}$.

\section{Conclusion}

Through the research of the various transition metals salts catalysts, an optimization condition was got. This method is really a valuable one which belongs to the range of green chemistry and has a good selectivity and yield in moderate condition.

\section{REFERENCES}

1. M. Ramstedt, C. Norgren, J. Sheals, D. Boström, S. Sjöberg and P. Persson, Inorg. Chim. Acta, 357, 1185 (2004).

2. J.E. Franz, M.K. Mao and J.A. Sikorski, Glyphosate: A Unique Global Herbicide, American Chemical Society, Washington, DC (1997).

3. J. Kobylecka, B. Ptaszyñski and A. Zwoliñnska, Monatsh. Chem., 131, 1 (2000).

4. J. Legendziewicz, P. Gawryszewska, E. Galdecka and Z. Galdecki, J. Alloys Comp., 275, 356 (1998).

5. D.P. Riley and D.L. Fields, J. Am. Chem. Soc., 114, 1881 (1992).

6. D.L. Fields, R.C. Grabiak and D.P. Riley, US Patent. No. 4898972 (1990).

7. C. Pinel, E. Landrivon, H. Lini and P. Gallezot, J. Catal., 182, 515 (1999).

8. J.E. Franz, US Patent. No. 3954848 (1976).

9. D.F. Toy, P. Forest and E.H. Uhing, US Patent. No. 3160632 (1964).

10. J.E. Franz, US Patent. No. 3950402 (1976).

11. D.P. Riley, D.L. Fields and W. Rivers, Inorg. Chem., 30, 4191 (1991). 